\title{
The Research of Environmental Accessibility in Riga Churches
}

\author{
Kristiāna Romanovska - Grīnberga, Andra Ulme, Riga Technical University, Latvia
}

\begin{abstract}
The topic of the research is the environmental accessibility of churches in Riga. It is equally important both in Latvia and worldwide. Environmental accessibility is generally perceived as removing obstacles for people with special needs. According to the universal design and its principles public spaces should provide equal accessibility for every member of society. The Laws and Constitution of Latvia provides equal rights for all citizens. Environmental accessibility problems most commonly occur in cultural monuments, which include some of the churches. In modern world Christianity is a tradition, words and rituals of God, as well as social assistance. This is the reason why it is crucial for it to be comprehensive, so that everyone could use provided services independently and be equally involved in the church's activities. This research analyses problems that occur in existent urban environment and examines 86 churches located in Riga. Observation and digital analysis methods are used in order to acquire measurements. Results are provided using graphical method. The subjects of the study are Christian denomination churches, that have been mentioned in Article 51 of the Latvian Civil Law, it includes Evangelical Lutherans, Roman Catholics, Orthodox Believers, Old Believers, Methodists, Seventh-day Adventists and Moses Believers (Judaism). Taking into consideration statistics and modern situation the study also includes some of the most widespread and active Christian denominations: Baptists, Pentecostals, Mormons, New Generations, Anglicans, New Apostles and Christians of the Evangelical Faith. The purpose of the research is to provide an overview of the current situation, as well as determine problems in environmental accessibility and guideline integration into sacred buildings. Research also aims to provide possible solutions for improving the quality of life of people with functional limitations. The study reflects on the significant shortcoming of churches located in Riga in meeting the guidelines and standards of public buildings. New buildings are more often to meet accessibility requirements and regulations, however, chosen solutions often lack practicality or do not provide easy usage.
\end{abstract}

Keywords: environmental accessibility, churches, functional limitations, equal opportunities in architecture

\section{Introduction}

The issue of environmental accessibility is important both in Latvia and worldwide. Elderly, people with disabilities, parents with young children and struggling individuals are the most likely to seek support and spiritual strength in churches. By its very nature church is a place of refuge, comfort and answers. Therefore, it must be able to provide services for every member of society on an equal basis. There is no comprehensive or regular analysis of the current situation in the field of environmental accessibility in Latvia. Convincing reports and studies from the Ombudsman as well as other sources show that environmental accessibility has not been fully addressed. Current situation restricts and suppresses the rights and freedom of people with disabilities, elderly and parents with young children [17]. There have been no studies conducted in Latvia regarding the state of environmental accessibility either in churches as a whole or their regions.

This research studies 86 Riga Churches of different denomination. It also uses expert opinion on various issues, including accessibility of environment, protection of cultural monuments and universal design. The aim of this paper is to present current situation, as well as problems regarding integration of the environmental accessibility principles and guidelines into sacred buildings. The goal is also to draw conclusions on possible solutions to the problem in order to improve the quality of life for people with functional limitations. To achieve this goal following tasks were performed: exploring and analysing theoretical material and legislative criteria; developing a survey criteria; conducting photo fixation and comparative analysis of 86 churches in Riga in order to evaluate current situation and identify problems in the area of environmental accessibility; composing a survey and questions for the interviews; selecting experts and conduct surveys and in-depth interviews to ascertain the experience and views of the various national authorities involved; based on the obtained information and legislation developing a methodology for the evaluation of Riga churches; inspecting 86 churches located in Riga (measurement and photo fixation, filling in the assessment questionnaire), making a percentage calculations of the environmental accessibility of Riga churches based on qualitatively developed criteria; summarizing the data obtained and presenting the results in graph form; drawing conclusions.

Methods used in the study: literature and legislative analysis, first survey (digital analysis and measurement), comparative analysis, expert surveys, expert interviews, benchmarking, second survey (digital analysis and measurement), percentage calculations and graphical analytical methods for 


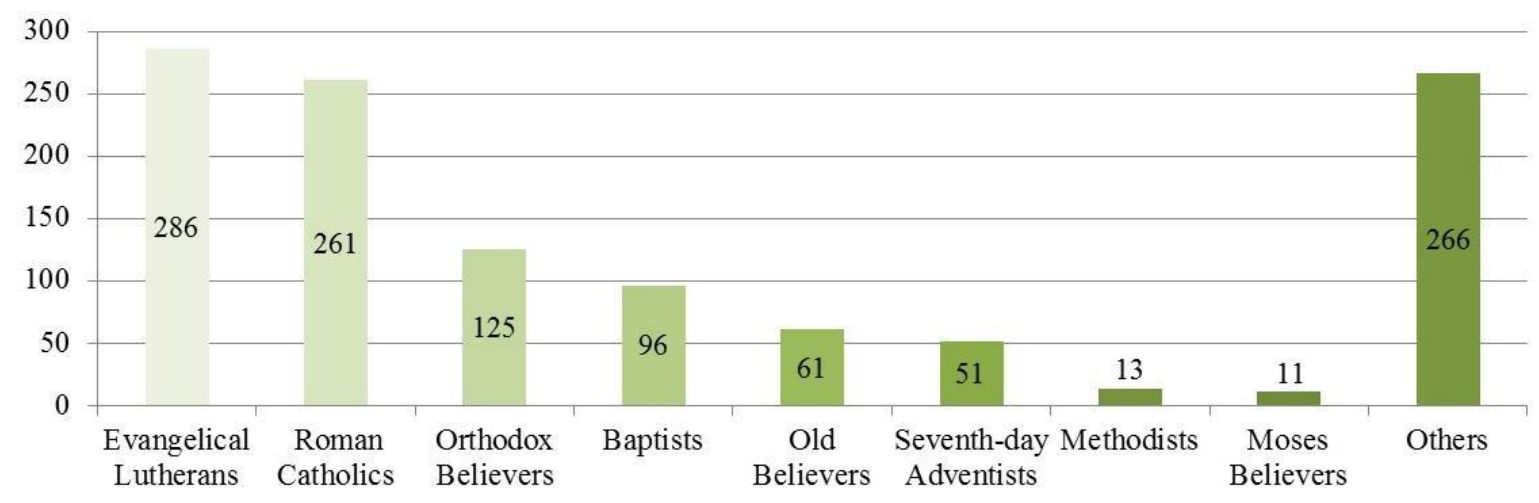

Fig. 1. Congregations registered in Latvia in 2017 [3]

demonstrating results. The scientific article is a new study in the field of engineering and architecture on the accessibility of the environment in Riga churches. It can be useful as a basis for identifying obstacles in churches of Riga city, or as a learning resource for industry, students, and any interested member of society, as well as to raise awareness to the issue.

\section{Analysis of the current situation}

Religion is an all-inclusive cultural system that roots deeply into existential views of the society. Since ancient times, Latvian citizens have been closely connected to religion, with certain denominations dominating in specific historical period. Nowadays churches are an essential part of the cultural heritage, as well as play an important role in lives of many people. This fact is confirmed by the news from the Ministry of Justice (TM) regarding submitted reports of religious organizations. The number of churches has increased significantly since the restoration of Latvia's independence. In 1990 there were 693 religious congregations registered, while at the end of 2017 the number was 1170 (see Figure 1) [3]. At its core the Church is both public space and the centre of spiritual life. In the 21 st century the design of public buildings is an important social responsibility, as well as an interdisciplinary strategic of the development process and a way to identify problems and find solutions. Every human consciousness is primarily concerned about one's well-being, satisfying specific needs, desires and rights, being independent and free, without creating any social or physical obstacles. The implementing of environmental accessibility guidelines in churches provides an opportunity for all members of the community to fully use the space, its elements and services.

The data of the National Commission of Medical Examination of Health and Capacity for Work (VDEĀVK) shows that based on the three year dynamics the number of individuals with disabilities tends to increase (see Figure 2) [9]. In 2016, the number of disabled people was higher by 6003 than in 2015 , but in 2017 the number increased by 5014 compared to 2016. Although the rose is less significant in the recent years, which is a positive factor, the proportion of people with disabilities is very high in relation to the total population of Latvia. According to the State Social Insurance Agency (VSAA), there are currently over 190 thousand people with disabilities in Latvia [20]. Individuals with disabilities do not form a universal community of people that has easily identifiable needs, obstacles and possible solutions for the accessible environment. Disabilities have many causes and types based on which it is possible to define several groups of disabilities that require different approaches in order to overcome obstacles: sight, hearing, physical disability, intellectual disability, psychosocial or mental disability and invisible disabilities (e.g. asthma, cardiovascular diseases, allergies, damage to various organs and impaired functionality) [8]. According to the Central Statistical Bureau (CSP), Latvia is also one of the European Union countries where the predominance of mortality over birth and predominance of emigration over immigrants has caused significant changes in the age composition of the population (see Figure 3). [4]. The proportion of children before working capability age (0-14 years) compared to the number of population has slightly increased since 2009 - from $14.1 \%$ to $15.9 \%$. The number of individuals in the age group of $65+$ has increased significantly - from $17.8 \%$ to $20.3 \%$, which is about one fifth of the total Latvian population. In addition to people with disabilities and elderly, it should be taken into account that the following groups of people have limited mobility: children under 4 years accompanied by an adult (103.6 thousand or $5.3 \%$ of the total population); people with temporary disabilities (after injury or illness); overweight individuals; very small or tall people; individuals with suitcases, bags, etc. [9].

It is essential to find successful solutions while designing temples so that people with functional 


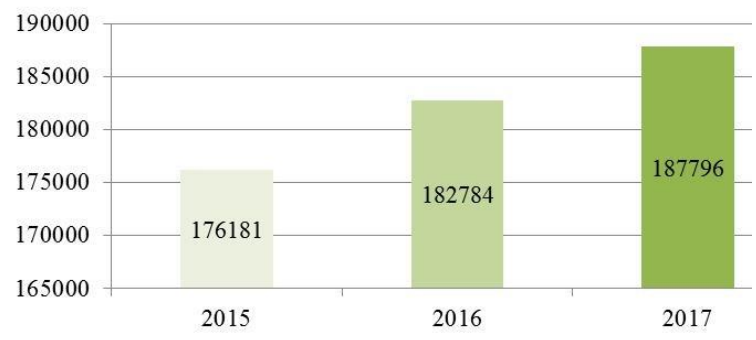

Fig. 2. The increase of the individuals with disabilities in the time period from 2015 to 2017 [9]

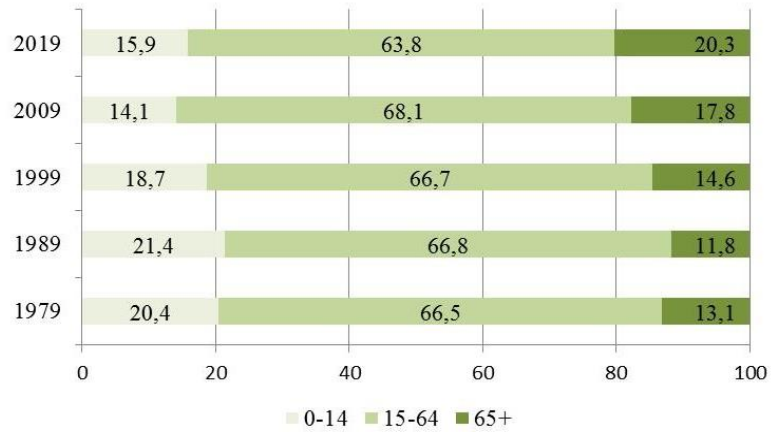

Fig. 3. Population by the age group at the beginning of the year (thousands) [4]

limitation could carry activities on their own or with the minimal necessary help from others. Types of function limitations vary and require different needs to be met when defining a sacred building accessible to everyone. Evaluation of the current situation shows that it may not always be possible to adapt the environment to the needs of all individuals, however, good and qualitative results, as close to the maximum as possible, can be achieved by following basic accessibility principles [7]. The equal access to the environment has always been a major issue of the citizens' rights. In Latvia, the realization of accessibility in public buildings is governed by both national laws and adopted UN and EU documents. Sections 4, 5 and 9 of the Building Act define the requirements for the design of a public building, which should provide accessible environment, so that every public member can move around and use the building and its services accordingly. However, Article 9.1 mentions derogations where accessibility requirements may not be met, for example in protected areas, buildings of historical value (if it may result in losing their value) [15].

Creation of accessible environment is provided by Cabinet of Ministers (MC) regulations No. 331. "Regulations on Latvian Building Standard LBN 20815 "Public Buildings", Article 4. It requires providing a comfortable access and movements in public buildings, the necessary equipment (lifts, slopes) and access to information (audio and visual information, tactile surfaces, Braille) to people with functional limitations [12]. Compliance with the environmental accessibility requirements at all stages of the construction process, except in specific cases, is stipulated by Cabinet of Ministers Regulation No. 500
"General Building Regulations", Cabinet of Ministers Regulations No. 529 "Building Regulations" and Cabinet of Ministers Regulations No. 240 "General Regulations for Spatial Planning, Use and Building" $[11 ; 13 ; 14]$. European Union (EU) and United Nations (UN) documents in force regarding freedom, human rights, anti-discrimination and promotion of access: "Universal Declaration of Human Rights", "Convention for the Protection of Human Rights and Fundamental Freedoms", "Charter of Fundamental Rights of the European Union" and others $[1 ; 5 ; 6]$. With the support of European foundations, various organizations working in the field of integration for people with disabilities have developed accessibility guidelines for public buildings, their elements and public outdoor space. For example, "Guidelines for the Application of Building Standards for the Accessibility of Individuals with Disabilities", "Guidelines for the Accessibility of Individuals with Disabilities", "Guidelines for Environmental Accessibility in Public Buildings and in the External Environment by Universal Design Principles streets and public spaces".

Latvia has a well-structured and satisfaction legislation on environmental accessibility; however significant deviations from the requirements occur in the real life. It is possible that the problem is caused by the exceptions allowed by laws and regulations creating loopholes that are being used. No matter how organized and well through the legislation is some will choose to disregard it, if such option exists. In Latvia there have not been done any comprehensive analysis of the current situation regarding environmental accessibility in public. However, convincing reports from the Ombudsman and some studies, as well as other sources prove the existence of environmental and informational imperfections $[10 ; 17 ; 18 ; 19]$.

Some of the churches in Riga are significant cultural monuments with both local and national importance, which leads to their adaptation to the needs of visitors being a great challenge as well as a testament of the professionalism. The key to preservation of cultural heritages is to provide their usage to the public, while also preserving and not diminishing historical value. The protection of cultural heritage in Latvia is regulated by the Law of the Republic of Latvia - "the Protection of Cultural Monuments" [2], which define the types, prohibitions, rights of use, accounting, preservation, supervision and control of cultural monuments. In 1997, the Historical Centre of Riga was included in the UNESCO World Heritage List. In 2003 the Law on Preservation and Protection of Riga Historical Centre was taken [16]. In accordance with the law, the Riga Historical Centre Conservation and Development Council was established in the same year. 


\section{Methodology of research}

To ensure successful and reliable results, a thoroughly developed methodology has been strictly followed throughout the research. Required materials for an in-depth investigation of the situation has been chosen and classified according to their content: Latvian state laws, EU and UN regulations that are currently in force in Latvia, guidelines, literature on religious denominations and universal design. Source research and analysis has been made. A historically genetic method has been used in order to achieve the most objective and reasonable conclusions regarding necessity of the Church in human's life, historical development of denominations, the preconditions for the development of universal design worldwide and in Europe and Latvia. Benchmarking criteria was developed based on legislations and guidelines so that the problem would be easily detected while conducting the initial survey. In 2018, in the time period from 7 th of September to 5 th of November 86 churches in Riga have been surveyed (photo fixation, measurements). The obtained data is presented in the form of a table and diagram that reflect the existence of shortcomings of accessibility in Riga churches (see Fig. 4). During the research the author has also encountered other obstacles. Wrong addresses are provided for the Grace International Riga Baptist Church and 2nd Adventist Church. Armenian parish church denied access. The "Prieka Vests" Christian Church and the 3rd Adventist Church in Riga at the time of the survey were undergoing reconstruction, so were not eligible to be evaluated competently. Further research took place in the 79 churches of Riga.

From the time period from the 3rd of January 2019 to 8th of March 2019, expert surveys were conducted in 17 different churches in Riga (11 clergy and 6 church members). In the spring of 2019 two in-depth expert interviews were conducted. On the 10th of May, Agnes Rupenheit, Deputy Head of the Cultural Heritage Policy Department, discussed the feasibility and limitations of environmental accessibility requirements in cultural monuments. On May 24th, Ann Posahov, the Civil Engineer of the Planning and Design Organization Division of the Traffic Infrastructure Authority, discussed the prerequisites for the construction of ramps in a public outdoor space.

Based on the legislation of Latvia and the information obtained, an evaluation questionnaire for in-depth inspection of churches in Riga (surveys and photo fixations) was carefully elaborated. Seven major evaluation categories were selected: ramps, stairs, thresholds, doors, information, public halls and corridors, other criteria (elevator, toilets, parking, playrooms and religious instruction). Required criteria were applied to each category.

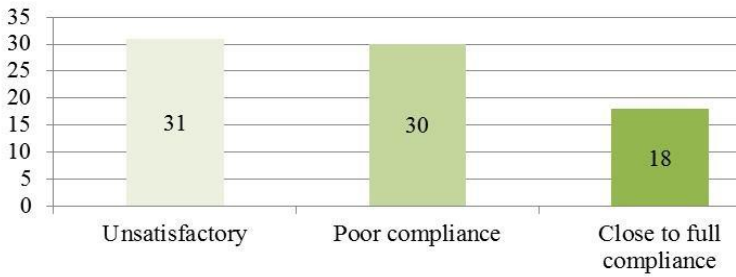

Fig. 4. The results of the First Survey of Churches in Riga [* from the author's personal archive]

From the 7th of June to 28th of July 2019, 79 churches in Riga were surveyed, which included photo fixation and measurements accordingly to the developed guideline. For comparison and analysis of the results percentage calculations of environmental availability were made. The results are presented both in the form of tables and diagrams.

\section{Results}

Accessible environment is essential for any member of society in order to feel accepted and equal, as well as to provide a successful social integration process. Churches are not only the spiritual centre of life, but also a public space that should meet the necessary accessibility requirements, as among its purposes is the ability to accommodate anyone in the need of services.

During the first survey (07.09.2018-05.11.2018) presented in the research, significant deficiencies were discovered in the fulfilment of the requirements and guidelines for accessibility of public buildings. The results are shown in the form of a bar graph (see Figure 4). 31 of the total surveyed churches encountered a major problem in providing access to all members of the society (need and lack of ramps, high thresholds that are difficult to overcome, lack of information, broken equipment, etc.). A tendency to improve the accessibility situation was recognized in 30 sacred buildings, however some functionality problems have occurred most likely due to lack of knowledge. 18 sacred buildings provide an easy access to anyone with minor disadvantages that do not endanger the health of the person. However, they can cause compilations and confusion, so it is advisable to make improvements based on good examples worldwide. During the surveys of some churches other obstacles were encountered: incorrect address information, private properties, construction work and denial of access - further research involves 79 churches located in Riga.

In order to acquire information on the current situation in churches of Riga, as well as acquaint expert opinion regarding accessibility of the environment, both closed and open questionnaires were used. A total of 17 experts from 17 different churches in Riga attended, including 11 clergy and 6 church members. Experts were asked to name the 


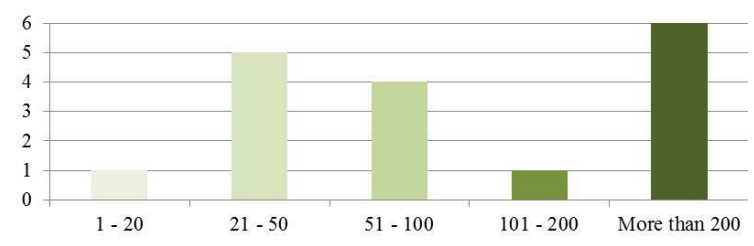

Fig. 5. Expert evaluation on attendance of the churches they represent [*]

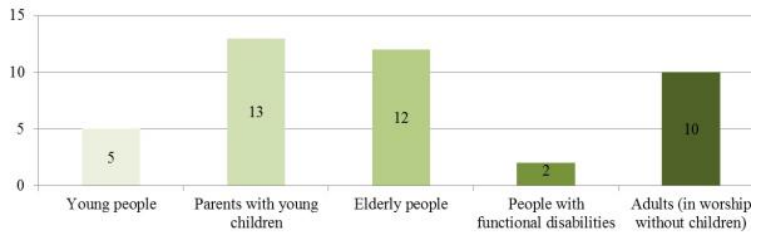

Fig. 6. Expert evaluations on dominant groups in their church events [*]

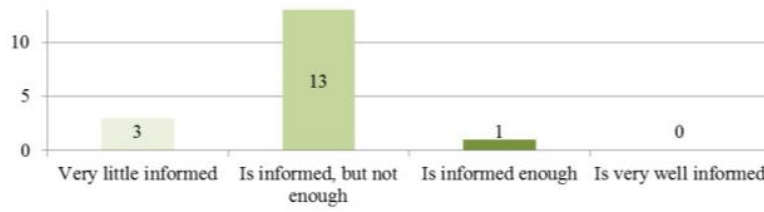

Fig. 7. Expert evaluations on public awareness about environmental accessibility [*]

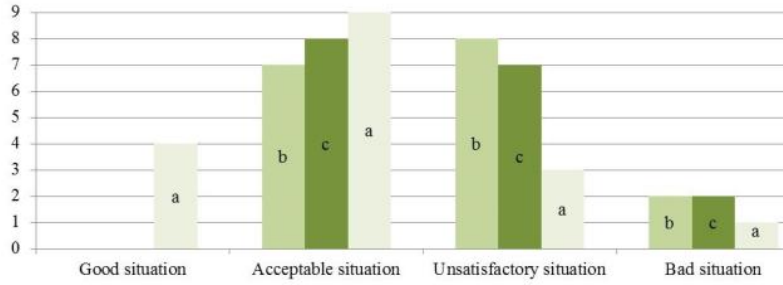

Fig. 8. Expert opinion on the state of environmental accessibility in Latvia, in churches and in the church they represent [from author's personal archive] $a$-expert's church, $b$-Latvia, $c$-churches in general estimated number of people who regularly attend services in their church (see Figure 5). Of course, when evaluating the results, it should be noted that the number of visitors directly dependents on the number of people in the particular congregation. However, the overall number of visitors during church events indicates that churches occupy an important place in society and are attended. Most experts have mentioned that they would wish for a higher attendance. Summarizing the results of the expert survey (see Figure 6), it can be concluded that the dominant groups are parents with children (marked 13) and the elderly (marked 12). Two of the experts have listed people with disabilities as one of the dominant groups in Church life. The results reflect that most of the temple visitors are people with limitations and it is essential to provide an accessible and obstacle free environment to them. Many members of the society do not see difficulties in going to the church, climbing the stairs, choosing a comfortable seat and attending church services or other church activities. Perhaps it is due to the fact that most are not forced to deal with major obstacles in their life or have not acquainted people with functional limitations. This leads to some not noticing in their fast-paced daily routine that not everyone is able to do it as easily. In society the topic of creating an accessible public environment is mostly associated with individuals with disabilities, disregarding the fact that the majority of the Latvian population is a potential user of accessible environment - people with functional disabilities, elderly people, parents with young children and other members of society in specific life situations. It is essential to invite all members of the society to the churches, giving everyone the opportunity to be there, providing the help to everyone who has any difficulties or requirements. There is a high possibility that adapting churches to the requirements of environmental accessibility would result in a higher attendance of services and events.

Problems can also occur due to the intolerance of others, neglect and lack of knowledge, that is further expressed through negative body language or verbal condemnation. For instance, even if the church meets all accessibility requirements, but brings discomfort to the person with special needs, it most likely will not be attended. Insufficient knowledge is also reflected in the opinion of experts on people's awareness and understanding in the field of accessibility (see Figure 7). Most experts (13) note that public awareness exist, however is not sufficient and it is necessary to promote awareness among local authorities, parties involved in the construction process and the general public in order to develop positive interactions and tolerant environment. The execution of the regulation requirement only formally should be prevented as much as possible. Public access to all users should be maximized.

Experts were asked to express their opinion on the state of environmental accessibility in the churches they represent, in Latvia and in churches in general (see Figure 8). Most experts (9) consider the accessibility situation in their church to be acceptable, and eight out of questioned find it acceptable in the churches as a whole. Some based their opinion not on the direct accessibility situation of the building elements, but on the support and assistance of the clergy. Possibly due to lack of information it is noticeable that such elements like markings, the presence and correct design of handrails, the presence of edges at the required height $(0.10 \mathrm{~m})$, manoeuvring areas, pendant slopes and widths, information signs and other factors have not been taken into account. Some of these do not endanger people's life, but can lead to confusion and result in difficulties in moving and orientating through the church. Seven experts consider the situation of accessibility in Latvian churches to be generally unsatisfactory. In terms of environmental accessibility in Latvia as a whole, most (8) see the situation as unsatisfactory. 


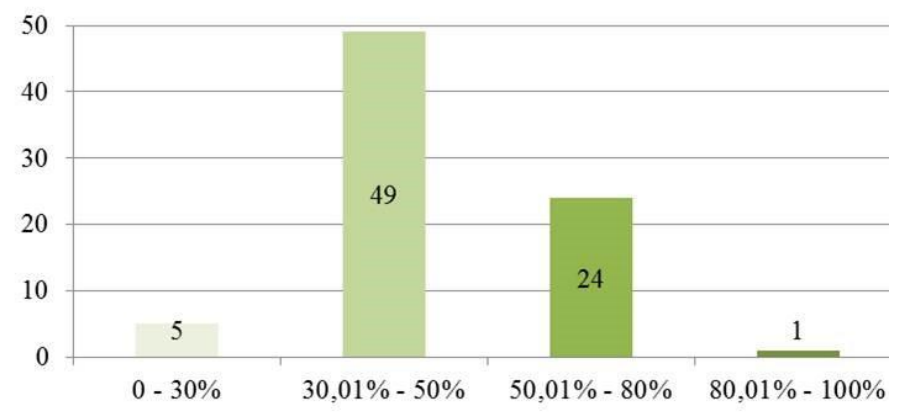

Fig. 9. Compliance of Riga churches with accessibility requirements [*]

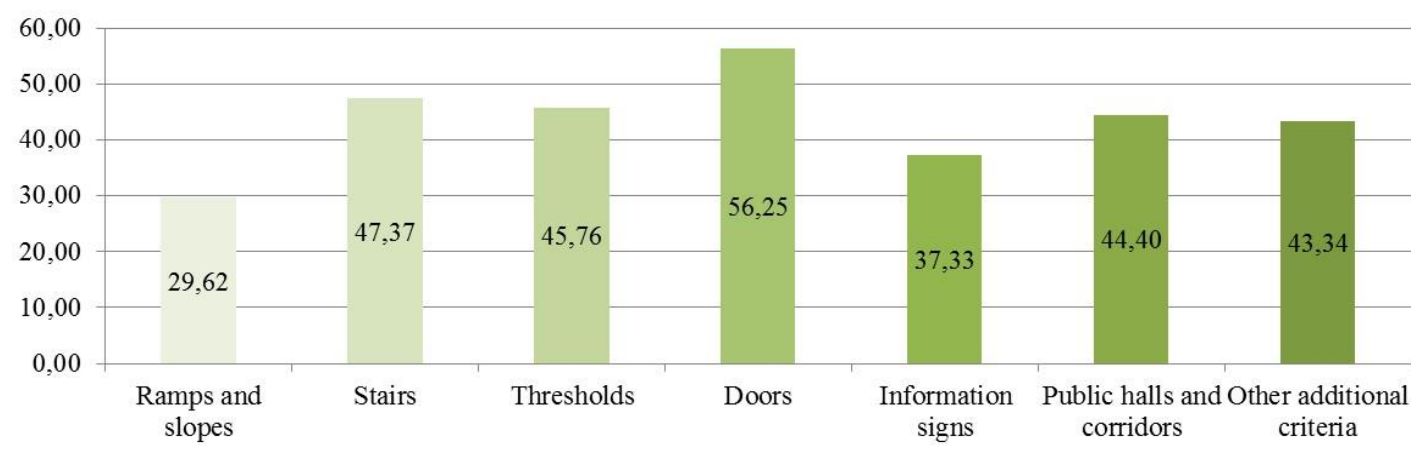

Fig. 10. Eligibility of elements of Riga Churches to the environmental accessibility requirements [*]

The majority of experts believe that accessibility requirements cannot be fully met in all buildings; however, it is essential to ensure the necessary accessibility of public buildings to everyone, taking into account the maximum amount of target audience. Several suggestions to improve current situation in Latvia were made: managing authority representatives would be more willing to listen and implement ideas to improve the situation of environmental accessibility in cultural monuments; declare whether building is meant for people or people are meant for the building; set stricter requirements for the environmental accessibility; apply penalties if the building does not meet accessibility requirements, specify and shorten conciliation procedures, as well as help churches find financial resources, as not all are large enough to raise donations for the construction. $50 \%$ mark based on the average accessibility. Out of them five churches fall within the range of $0 \%$ to $30 \%$ and forty-nine within the range of $30.01 \%$ to $50 \%$. Twenty-five sacred buildings are above the $50 \%$ mark, of which only one exceeds $80 \%$ of the accessible environmental compliance value.

In order to define elements that have the greatest non-compliance with environmental accessibility requirements, the average percentage for each element among surveyed churches were calculated (see Figure 10). The results identify that "door" is the infrastructure that meets most of the environmental accessibility requirements in the surveyed churches $(56.25 \%)$. This is due to the fact that since ancient times most of the churches were designed to have large, wide and grand doors, which makes it accessible to people with functional limitations nowadays. The other elements are below the average of $50 \%$, which is not satisfactory. The most inadequate infrastructures are information signs $(37.33 \%)$, ramps and slopes $(29.62 \%)$. Most of the informational signs use fonts and word size that does not meet the requirements, as well as can be too shiny and are not visible during all times of the day. The majority of the surveyed churches lack signs for people with functional limitations with information and instruction on the access of the building. Most of the churches that were surveyed require a ramp, as they do not have a built one, as well as part of the current projects does not meet environmental accessibility requirements.

The accessible environment consists of many details, which can often serve as obstacles for people with functional limitations. For instance, the ramp is appropriately installed; however, door was not being taken into consideration: it either opens in a way that makes wheelchair access impossible, or there is no access beyond the door. The opposite can be also true - door and public space were meant to be open to everyone, but are not accessible to everyone. The solution for accessibility is needed by the whole community, as a large part will become parents, as well as eventually everyone ages.

Overall during the evaluation of the acquired results, as well as research of previous studies and observations in the field of the environmental accessibility in Latvia $[10 ; 17 ; 18 ; 19]$, a significant and addressable accessibility issues were pointed 
out, resolving which will result in providing a maximally equal life to everyone. It is impossible to fully solve all problems in order to reach the ideal, due to the complexity of adapting one environment to such a diverse audience, given the physical and social differences between the individuals and society as a whole. However, responsibility, tolerance and cooperation are the key to achieve the most appropriate and effective accessibility solutions for public buildings that will be able to satisfy the vast majority of society members.

\section{Conclusions}

Worldwide, as well as in Latvia, the amount of people who have various movement limitations is rising significantly, and it is not always people with special needs. By evaluating the situation in Latvia as a whole and by highlighting a particular group churches - significant problems in the area of environmental accessibility can be identified. However, a positive trend can be notable, as attention to the accessibility question has been increasing in the recent years, as well as cooperation with foreign experts and learning from their experience is taking place.

The research of the scientific article convincingly reflects the effectiveness of the survey of Riga churches, identifying existing obstacles and main problem groups, which facilitate the analysis of the situation and development of possible solutions. It is advisable to perform this type of research in other sectors of the public environment and services as well.

The accessibility problem groups in the churches are ramps and signboards - their absence or inadequacy of existing ones. Some of the churches in Riga due their cultural and historical status have various construction restrictions and encumbrances in order to preserve as much historical value of the object and its elements as possible. While considering possible solutions for creating accessible environment in cultural monuments, it is essential for the benefits to overweight the loss of parts of the heritage that will be irrevocably gone. All solutions need to consider consequences and comparability with the particular historical building. It is recommended to use light weighted structures, which can be easily transformed in case of need, for example into various mobile ramps and lifts. Nowadays, with the advance technologies there is a wide range of labelling options (adhesive, screwed on, embedded as surface coating) that can be easily used in public areas without damaging the surface, as well as replaced and disposed of when needed. The design of the existing information signs indicates a lack of knowledge, so it is advisable to carefully study the accessibility requirements before signs are created and used in the public domain. In Latvia the legislation on environmental accessibility for people with functional limitations is mostly well organized, however in reality it has not been fully executed in many places. It should also include solutions that are acceptable for cultural monuments, as well as specific penalties for violating certain accessibility requirements in order to reduce the chances of problems occurring when projects are being realized. One of the major obstacles for the churches is the lack of funding to develop, coordinate and perform projects for the improvement of current situation.

A creation of accessible environment includes not only the elimination of physical barriers, but also providing opportunities for people with functional limitations to engage in everyday social activities. It is essential to educate others on the topic of people with disabilities, parents with young children and the elderly, creating tolerance and understanding. It is advisable to provide information about good practices through various events and media. As a result of a successful communication and cooperation between the community, responsible individuals and institutions, it is possible to create the friendliest and accessible environment for everyone in Latvia, as well as to ensure equal access to the services. In other case visitors will be denied one of or even the only opportunity to socialize. The aim of the research has been achieved, tasks have been fulfilled and the authors will continue to work on informing the public about the accessibility of the environment. It is planned to carry out various researches and summarize their results in scientific articles.

\section{References}

1. ANO. Vispārējā cilvēktiesību deklarācija. Francija: Parīze, 1948.

2. Augstākā Padome. Latvijas Republikas likums Par kultūras pieminekḷu aizsardzību. Latvija: Rīga, 1992.

3. Centrālā statistikas pārvalde. Latvijas statistikas gadagrāmata 2018. Latvija: Rīga, 2019, p. 113. ISBN 978-998406-513-7.

4. Centrālā statistikas pārvalde. Demogrāfjija 2019. Latvija: Rīga, 2019. p. 19. ISBN 978-9984-06-535-9

5. Eiropas Padome. Cilvēka tiesību un pamatbrīvību aizsardzības konvencija. Itālija: Roma, 1950.

6. Eiropas Parlaments, Padome un Komisija. Eiropas Savienības pamattiesību harta. Francija: Nica, 2000.

7. Invalīdu un vinu draugu apvienība „Apeirons”. Ergonometrija, 1.burtnīca. Latvija: Rīga, 2002. p. 11.

8. Invalīdu un viṇu draugu apvienība „Apeirons”. Rokasgrāmata Reǵionālais sabiedriskais eksperts cilvēku ar invaliditāti jautājumos. Latvija: Rīga, 2006, p. 10.

9. Labklājības ministrija. Apvienoto Nāciju Organizācijas Konvencijas par personu ar invaliditāti tiesībām īstenošanas pamatnostādṇu 2014.-2020. gadam īstenošanas plāns 2018.-2020. gadam. Latvija: Rīga, 2018, p. 6-8. 
10. Labklājības ministrija. Plāns pieejamas vides veidošanai Latvijā 2019.-2021. gadam. Latvija: Rīga, 2019.

11. Ministru kabinets. Ēku būvnoteikumi. Latvija: Rīga, 2014.

12. Ministru kabinets. Latvijas būvnormatīvs LBN 208-15 „Publiskas būves”. Latvija: Rīga, 2015.

13. Ministru kabinets. Vispārīgie būvnoteikumi. Latvija: Rīga, 2014.

14. Ministru kabinets. Vispārīgie teritorijas plānošanas, izmantošanas un apbūves noteikumi. Latvija: Rīga, 2013.

15. Saeima. Būvniecības likums. Latvija: Rīga, 2013.

16. Saeima. Rīgas vēsturiskā centra saglabāšanas un aizsardzības likums. Latvija: Rīga, 2003.

17. Tiesībsargs. Latvijas Republikas tiesībsarga 2016.gada ziņojums. Latvija: Rīga, 2017.

18. Tiesībsargs. Latvijas Republikas tiesībsarga 2017.gada ziņojums. Latvija: Rīga, 2018.

19. Tiesībsargs. Latvijas Republikas tiesībsarga 2018.gada ziņojums.Latvija: Rīga, 2019.

20. Dārziṇa, L. VSAA maksājumi cilvēkiem ar invaliditāti [online 03.11.2019.]. https://lvportals.lv/skaidrojumi/301866vsaa-maksajumi-cilvekiem-ar-invaliditati-2019

\section{AUTHORS:}

Kristiāna Romanovska - Grīnberga obtained Professional Bachelor's degree in Art and Interior Design in the Riga Technical University, 2016, and is currently acquiring Professional Master's degree in Material Technology and Design in the Riga Technical University. Work experience: trainee - interior designer, SIA „Simino Furniture”, interior designer, interior architect, technical draftsman, SIA „Forma”. Phone + 37122193793. Scientific interest is related to the urban and peri-urban areas' revitalization through regeneration of degraded areas and objects. It promotes environmental friendly and sustainable territorial growth as well as development and provision of environmental accessibility in all spheres of life, in order to maximize the self-sufficiency and independent living of individuals with disabilities. It is too early to talk about awards as scientific research is still ongoing as well as negotiations with the Latvian Designers' Union are taking place. Address: Institute of Design Technologies, Riga Technical University, Kipsalas Str. 6, Riga, LV-1048, Latvia. E-mail: kristianarom@inbox.lv

Andra Ulme, Dr. arch., Associated Professor of Riga Technical University, Faculty of Materials Science and Applied Chemistry, Institute of Design Technologies. Academic work experience: Associated Professor at RTU since 2015. Professional work experience: interior designer, interior architect, specializing in public and private interiors, specializing in hotel interior design, has completed more than 20 projects in suburbs over the last ten years, mostly in luxury style. Scientific activities: The author of more than 45 publications about spatial design, architecture, urban planning, history of architecture, accessibility of environment, Universal Design, educational problems, published in Latvia, Estonia, Lithuania, Croatia, Poland, Portugal, Italy, Greece, Russia. Since 2017, an international expert of architecture, design and art. Research interests: architecture, contemporary problems of Architecture and Design education, VR, exploration of unutilized hidden resources and research of utilization possibility of these resources to promote of the development of national economy of Latvia. Address: Institute of Design Technologies, Riga Technical University, Kipsalas Str. 6-432, Riga, LV-1048, Latvia. E-mail: andra.ulme@rtu.lv Phone + 37167089256

Kopsavilkums. Zinātniskā raksta pētījuma joma ir vides pieejamība Rīgas dievnamos. Tā ir aktuāla gan Latvijā, gan pasaules mērogā. Vides pieejamība pārsvarā tiek uztverta kā šḳēršlu likvidēšana cilvēkiem ar īpašām vajadzībām. Balstoties uz universālo dizainu un tā principiem publiskajām telpām, jābūt pieejamām ikvienam sabiedrības loceklim. Latvijas Satversme un tiesību akti paredz vienlīdzīgu tiesību nodrošināšanu visiem iedzīvotājiem. Vides pieejamības problēmas sastopamas kultūras pieminekḷos, no kuriem daļa ir dievnami. Mūsdienās kristīgā ticība ir gan tradīcija, Dieva vārdi un rituāli, gan sociālā palīdzība. Tāpēc dievnamam ir jābūt visaptverošam, tādam, lai ikviens sabiedrības loceklis spētu lietot tā pakalpojumus, būt neatkarīgiem un līdzvērtīgi iekḷauties baznīcas aktivitātēs. Pētījumā tiek apskatītas problēmas reālā pilsētvidē un apsekoti 86 Rīgas dievnami. Ar novērojumu un digitālās analīzes palīdzību veikti mērījumi un ar grafoanalīiskajām metodēm attēloti rezultāti. Par pētījuma objektu izvēlēti kristīgo konfesiju dievnami, kuri minēti Latvijas Civillikuma 51. pantā - Evanǵēliskie luterāṇi, Romas katoḷi, pareizticīgie, vecticībnieki, metodisti, septītās dienas adventisti un Mozus ticīgie (judaisti). N̦emot vērā statistiku un esošo situāciju, pētījumā ietvertas arī dažu mūsdienās izplatītu un aktīvu kristīgo konfesiju draudzes: baptisti, vasarsvētki, mormoṇi, jaunā paaudze, anglikāṇi, jaunapustuḷi un evanǵēliskās ticības kristieši. Raksta mērḳis ir sniegt priekšstatu par esošo situāciju un problēmām vides pieejamības principu un vadlīniju integrēšanai sakrālajās celtnēs, kā arī veikt secinājumus par problēmas iespējamajiem risinājumiem dzīves kvalitātes uzlabošanai cilvēkiem ar funkcionālajiem ierobežojumiem. Pētījumā atspoguḷotas Rīgas dievnamu būtiskas nepilnības publisko ēku vides pieejamības vadlīniju un standartu izpildē. Jaunbūvēs biežāk ievērotas pieejamības prasības un normatīvi, tomēr, ne vienmēr izvēlētie risinājumi ir ērti lietojami un praktiski. Latvijā nav veikti pêtījumi par vides pieejamības situāciju ne dievnamos kopumā, ne atsevišķos reǵionos. Zinātniskais raksts ir jauns pētījums inženierzinātņu nozarē un arhitektūrā par vides pieejamību Rīgas dievnamos. Raksts var būt lietderīgs kā bāze Rīgas pilsētas dievnamu šķēršlı identificēšanai vai kā izzinošs materiāls nozares pārstāvjiem, studentiem un ikvienam interesentam no sabiedrības, kā arī uzmanības vēršanai uz šīs problēmas aktualitāti. 